\title{
Nutritional, antinutritional and phenological characterization of promising forage species for animal feeding in a cold tropical zone
}

\author{
Caracterización nutricional, antinutricional y fenológica de especies forrajeras \\ promisorias para alimentación animal en zona tropical fría
}

Lesvy Ramos; José Edmundo Apráez²; Kris Stephany Cortes ${ }^{3}$; José Julián Apráez ${ }^{4}$

\begin{tabular}{ll}
\hline \multicolumn{1}{c}{ ARTICLE DATA } \\
\hline 1 & $\begin{array}{l}\text { Professor, MSc, Zoot, Universidad de Nariño. Pasto, } \\
\text { Colombia lesvyramos@yahoo.com }\end{array}$ \\
$2 \quad$ Professor, PhD, Zoot, Universidad de Nariño. Pasto, \\
Colombia eapraez@gmail.com \\
$3 \quad$ Researcher, Esp, Zoot, Universidad de Nariño. \\
Pasto, Colombia kris2090@hotmail.com \\
$4 \quad$ Professor, PhD, I.A, Universidad de Nariño. Pasto, \\
Colombia apraez.julian@gmail.com \\
\hline
\end{tabular}

Cite: Ramos, L.; Apráez, J.; Cortes, K.; Apráez, J. (2021). Nutritional, antinutritional and phenological characterization of promising forage species for animal feeding in a cold tropical zone. Revista de Ciencias Agrícolas. 38(1): 86-96

doi: https://doi.org/10.22267/rcia.213801.152

Recived: September 052019.

Accepted: April 132021.

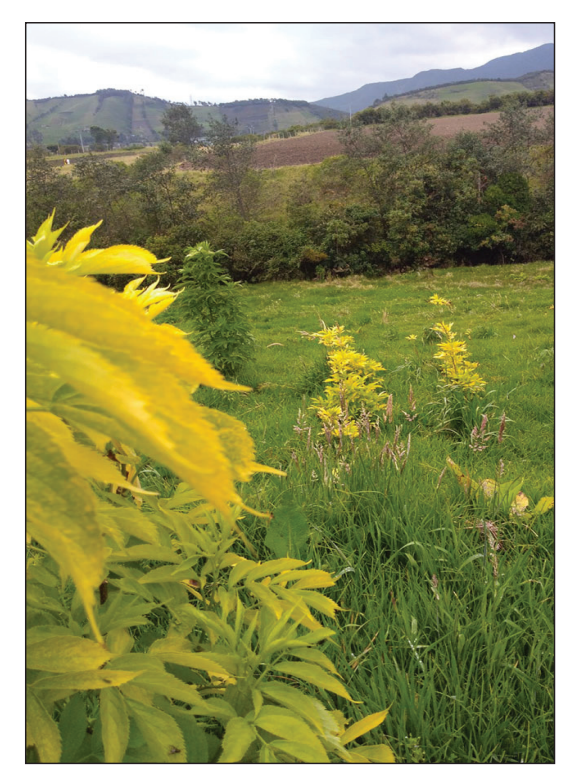

\section{ABSTRACT}

The search for forages with high biomass production and high nutritional content has made it possible to find food alternatives that, due to their nutritional benefits and resistance to adverse environmental factors, are the best option for herbivores. With the knowledge of farmers, producers and the experience of researchers, 12 species most frequently used in animal feeding were selected, identified and classified in the University's PSO herbarium of the University of Nariño. These were phenologically, nutritionally and antinutritionally characterized. Of these species, four belonged to the Asteraceae family; the Fabaceae, Adoxaceae and Malvaceae families were represented by two species; the Salicaceae and Cucurbitaceae families were represented by one and were propagated in nursery. In the nutritional composition, the Retamo (Genista monspessulana) stood out for its high dry matter content with $34.2 \%$. Unlike the Chauchilla (Cyclanthera brachystachya), with $8.79 \%$, the Sauco (Sambucus peruviana) had a higher content of protein $25.93 \%$, followed by Abutilon (Abutilon pictum) with $23.42 \%$. Chauchilla (Cyclanthera brachystachya) had the highest crude fiber content, with $21.59 \%$, NDF of $38.06 \%$, and FDA $27.23 \%$. Tannins were the most common secondary metabolites in the species evaluated with moderate or low levels; sterols were present at low levels, and saponins and alkaloids yielded negative values.

Keywords: feeding; forage; metabolite; nutrition; promising.

\section{RESUMEN}

La búsqueda de forrajes con alta producción de biomasa y alto contenido nutricional, ha permitido encontrar alternativas alimenticias que por sus bondades nutricionales y resistencia a factores ambientales adversos, se constituyen en la mejor opción para los herbívoros. Con el conocimiento de campesinos, productores y la experiencia de los investigadores, se seleccionaron 12 especies usadas con más frecuencia en alimentación animal, se identificaron y clasificaron en el herbario PSO de la Universidad de Nariño, se caracterizaron fenológica, nutricional 
y antinutricionalmente. De estas especies, cuatro pertenecen a la familia Asteraceae, las familias Fabaceae, Adoxaceae y Malvaceae representadas por dos especies y una, para las familias Salicaceae y Cucurbitaceae, las cuales se propagaron bajo vivero. En la composición nutricional el Retamo, Genista monspessulana se destacó por su alto contenido de materia seca con $34.2 \%$ a diferencia de la Chauchilla, Cyclanthera brachystachya, con un 8.79\%, el Tilo (Sambucus peruviana) tuvo un mayor contenido de proteína 25.93 \%, seguido del Abutilón (Abutilon pictum) con 23.42\%, el mayor contenido de fibra cruda se presentó en la Chauchilla, (Cyclanthera brachystachya) con $21.59 \%$, FDN del 38.06\% y FDA 27.23\%. Los taninos fueron los metabolitos secundarios de mayor presencia en las especies evaluadas con niveles moderados o bajos, los esteroles en niveles bajos y valores negativos para saponinas y alcaloides.

Palabras clave: alimentación; forraje; metabolito; nutrición; promisoria.

\section{INTRODUCTION}

In the Andean area of the department of Nariño, it is common to find productive units of herbivorous animals such as guinea pigs and rabbits, bovines and ovines, both in traditional and technified production systems. These animals are generally fed with Lolium $s p$, Medicago sativa, trifolium $s p$, among others. Due to their superficial roots, these plants are dramatically affected in dry seasons or prolonged rains, presenting a reduction in biomass production, which directly affects the productivity of the animals, in addition to the detriment in the quality of the soils.

In this regard, Silva et al. (2018) mention that in most livestock farms, improved foreign pastures have been established, which constitute the main food source for herbivores. These pastures have adaptation difficulties and resistance to water stress due to excess water (rainy season) or lack of it (dry season), affecting the performance and quality of the forage, with direct repercussions on animal performance.

All agricultural production schemes should follow the principles of sustainability, trying to avoid the deterioration of the ecosystem. Due to cultural factors, Colombian livestock tends to threaten environmental conservation and contaminate water sources, which cause soil compaction, loss of plant cover, and deforestation. In this sense, adapted native and foreign trees and shrubs can strengthen the soil-plant-animal symbiosis, thus bringing about the recovery the soils by capturing groundwater and assisting in nitrogen fixation, aeration, nutrient recycling, microbiota recovery, soil, and erosion protection, among other benefits. Polanía and Rendón (2009) state that traditionally, the land use that has been taking place in Colombia and in many Latin American countries has underestimated the tree and / or shrub resource, without considering it as an integral component within the productive functions and generators of eco-systemic services in agricultural activity.

Gómez et al. (2002) affirm that promising plant species do not form a specific group in terms of their botanical classification. They include a high number of perennial woody species that have forage potential due to either their foliage or their fruits. There is a considerable number of native and introduced arboreal and shrub forage species adapted to a wide range of agro-ecological zones, which have turned out to be persistent and productive, with the possibility of being used in animal feed as an arboreal component in silvopastoral systems (SPS). 
The research aimed to find other food sources in shrubs and trees with good nutritional content, which contribute to fill up the requirements of the animals, seeking a lower cost based on their easy establishment and management. With this purpose, the research allowed the phenological and nutritional characterization and identification of antinutritional factors of 12 promising forage species, with the potential to be used in animal feeding, available in the high tropics of the high plateau of Nariño.

\section{MATERIALS AND METHODS}

The fieldwork was carried out in the forest reserve area of the Experimental Botana Farm, property of the University of Nariño. The farm is located 8 kilometers from the city of Pasto, in the Catambuco village, located in the Montano Humid Forest life zone (bh-M), at a height of 2820 masl, with geographic coordinates $1^{\circ} 0.9^{\prime} 40.6^{\prime \prime} \mathrm{LN}$ and $77^{\circ} 16^{\prime} 44.6 \mathrm{LO}$, south of the municipality of Pasto, department of Nariño, Colombia. The average temperature is $12^{\circ} \mathrm{C}$ and the average annual rainfall is $715 \mathrm{~mm}$ (IDEAM, 2018).

Taking into account that this research is descriptive, twelve plant species were identified thanks to farmers, producers, and researchers who recognized them as promising for feeding herbivorous animals. The samples were collected according to the protocol established by the PSO (Pasto) herbarium of the University of Nariño. For each species, two complete replicas were taken including stem, leaves, flower and / or fruit. These were placed on sheets of newspaper, subsequently stacked and taken to the herbarium for identification and classification. To do so, information regarding their common name, date and place of collection, and the agroecological characterization of the area was included.

The multiplication of the floristic material was carried out in the farm's nursery, which has an area of 48 square meters with a $1.80 \mathrm{~m}$-high poly-shade cover. Initially, the adaptation of the facilities took place as well as the construction of the beds for germination, the installation of the irrigation system, and the preparation of the substrate. The substrate was obtained by mixing 3 parts of fertile soil, 1 part of rice husk and 1 part of organic matter for the propagation of plant material. Then, the plant material was collected: seeds and cuttings that were later sown. During the propagation time, all the tasks concerning irrigation, prevention, and control of pests and diseases were carried out to obtain healthy plants.

For the bromatological assessment, approximately 800 grams of fresh forage of the selected species were sent in two replicas to the Specialized Laboratories of the University of Nariño - bromatology section. There, the nutritional content and antinutritional factors of the species in the study were evaluated. The contents of Dry Matter (DM) were determined, as well as those of Crude Fiber (CF), Neutral Detergent Fiber (NDF), Acid Detergent Fiber (ADF), Ethereal Extract (EE), Crude Protein (CP), Nitrogen Free Extract (NFE) and Ash (A). Regarding secondary metabolites, the contents of saponins, tannins, sterols, and alkaloids were evaluated using qualitative phytochemical techniques. The process was conducted in a way that for a parameter to be classified as positive, the convention had to appear at least in two tests. This was done taking into account the protocols and procedures for analysis based on the techniques of the Association of Official Analytical Chemists (AOAC, 2016). 


\section{RESULTS AND DISCUSSION}

Floristic inventory. Based on the experience of farmers, local producers, and researchers, 12 promising plant species were cataloged for feeding herbivorous animals. The plants were taxonomically classified by the PSO herbal Universidad de Nariño (Table 1).

Four out of the 12 species identified belong to the Asteraceae family. One of the families is mostly used in food, such is the case of $T$. diversifolia, which presents high biomass yields; therefore, it can be consumed by different animals. T. diversifolia can be considered an exceptional plant genetic resource due to its high protein value, coupled with the fact that it is used in grazing or as forage for ruminants and monogastrics (Pérez et al., 2009).

The Fabacea, Adoxacea and Malvacea families were represented by two species corresponding to $16.6 \%$ each; $8.3 \%$ were from the Salicacea and Cucurbitacea families. One of the greatest expressions of the long process of evolution of life is the genetic diversity of tropical plants, whose number and taxonomy have not yet been completed by science.

Multipurpose trees and shrubs exemplify immense natural potential in tropical regions of the world. Trees with forage potential are an important example of this natural resource. Paradoxically, there is only incipient research on the matter despite the urgent need for sources of protein and / or energy for the diets of domestic animals for zootechnical use used by man. (Gómez et al., 2002).

Phenological measures. The phenological measurements taken allow elucidating the adaptation of the plants to the environmental factors of the study area and at the same time the ease of multiplication in nursery conditions (Table 2).

Table 1. Taxonomic Classification of Forage Plants.

\begin{tabular}{lll}
\hline \multicolumn{1}{c}{ Common Name } & \multicolumn{1}{c}{ Family } & \multicolumn{1}{c}{ Species } \\
\hline Tilo & Adoxaceae & Sambucus peruviana L. \\
Te forrajero & Fabaceae & Otholobium munyense (J.F.Macbr.) J.W.Grimes \\
Sauce llorón & Salicaceae & Salix humboldtiana Willd. \\
Sauco & Adoxaceae & Sambucus nigra L. \\
Retamo & Fabaceae & Genitsa monspessulana (L.) L.A.S. Johnson \\
Resucitado & Malvaceae & Hibiscus rosa sinensis L. \\
Colla & Asteraceae & Verbesina arborea Kunth \\
Chilca & Asteraceae & Baccharis latifolia (Ruíz \& Pav.) Pers. \\
Chauchilla & Cucurbitaceae & Cyclanthera brachystachya (Ser.) Cogn. \\
Altamisa & Asteraceae & Ambrosia arborescens Mill. \\
Abutilón & Malvaceae & Abutilón pictum (Gillies ex Hook. \& Arn.) Walp. \\
Botón de oro & Asteraceae & Tithonia diversifolia ( Hemsl.) A. Gray \\
\hline
\end{tabular}


Ramos et al. - Forage species for animal feeding

Table 2. Phenological measurements of forage species.

\begin{tabular}{|c|c|c|c|c|c|c|c|}
\hline \multirow{2}{*}{$\begin{array}{l}\text { Evaluated } \\
\text { Parameter }\end{array}$} & \multicolumn{7}{|c|}{ Forage species } \\
\hline & \multirow{2}{*}{$\begin{array}{c}\begin{array}{c}\text { Sambucus } \\
\text { peruviana }\end{array} \\
\text { Estaca }\end{array}$} & \multirow{2}{*}{$\begin{array}{c}\text { Otholobium } \\
\text { munyense }\end{array}$} & \multirow{2}{*}{$\begin{array}{c}\begin{array}{c}\text { Salix } \\
\text { humboldtiana }\end{array} \\
\text { Estaca }\end{array}$} & \multirow{2}{*}{$\begin{array}{c}\begin{array}{c}\text { Sambucus } \\
\text { nigra }\end{array} \\
\text { Estaca }\end{array}$} & \multicolumn{2}{|c|}{$\begin{array}{c}\text { Genitsa } \\
\text { monspessulana }\end{array}$} & \multirow{2}{*}{$\begin{array}{c}\begin{array}{c}\text { Hibiscus rosa } \\
\text { sinensis }\end{array} \\
\text { Estaca }\end{array}$} \\
\hline Propagation system & & & & & Semi & & \\
\hline Days to sprouting & 70 & - & 84 & 42 & - & & 94 \\
\hline Number of sprouts & 2 & - & 1 & 2 & - & & 3 \\
\hline \multirow[t]{2}{*}{ Days to emergency } & - & 55.5 & - & - & 49 & & - \\
\hline & & \multicolumn{6}{|c|}{ Forage species } \\
\hline \multicolumn{2}{|c|}{ Evaluated Parameter } & $\begin{array}{c}\text { Verbesina } \\
\text { arborea }\end{array}$ & $\begin{array}{c}\text { Baccharis } \quad C_{y} \\
\text { latifolia bro }\end{array}$ & $\begin{array}{l}\text { Cyclanthera } \\
\text { rachystachya }\end{array}$ & $\begin{array}{c}\text { Ambrosia } \\
\text { arborescens }\end{array}$ & $\begin{array}{c}\text { Abutilón } \\
\text { pictum }\end{array}$ & $\begin{array}{c}\text { Tithonia } \\
\text { diversifolia }\end{array}$ \\
\hline \multicolumn{2}{|l|}{ Propagation system } & Estaca & Estaca & Semilla & Estaca & Estaca & Estaca \\
\hline \multicolumn{2}{|l|}{ Days to sprouting } & 56 & 49 & - & 14 & 42 & 49 \\
\hline \multicolumn{2}{|l|}{ Number of sprouts } & 1 & 1 & - & 3 & 1 & 1 \\
\hline \multicolumn{2}{|l|}{ Days to emergency } & - & - & 66.5 & - & - & - \\
\hline
\end{tabular}

The propagation system, days to regrowth, number of sprouts and days of emergence were determined depending on the reproduction method. Nine species were propagated by stake and three by seed. Among them, $A$. arborescens stood out with a short regrowth period corresponding to 14 days on average and three shoots. The regrowth speed of $A$. pictum and $S$. nigra was 42 days and $H$. rosa sinensis 94 days. In the reproduction by seed, there were differences in the number of days to emerge with values of 49.0 and 66.5 for $G$. monspessulana and $C$. brachystachya, respectively.

These results are important since they represent the speed of appearance of foliage suitable as food for animals. In most plants, the leaves are the organs directly involved in the photosynthetic process. They can also be considered the place where the capture of the light energy necessary to drive the different chemical reactions vital for the growth and development of plants takes place (Taiz and Zeiger, 2010).

Nutritional composition. The results of nutritional composition are presented in Table 3, where a wide range of variation in dry matter can be observed in the evaluated material. G. monspessulana is the species that presented the highest percentage with 34.2\%. Conversely, C. brachystachya displayed the lowest percentage with $8.79 \%$. This characteristic was related to the time of year when the samples were collected. According to Ojeda et al. (2012), the lower the availability of water in the soils, the greater the edaphic evapotranspiration of the plants, which affects the moisture content of the analyzed plant tissue. Likewise, the DM content benefits the biomass yield if they are used with a previous conservation method, such as silage, hay, or flour. 
Table 3. Bromatological analysis of promising forage species.

\begin{tabular}{|c|c|c|c|c|c|c|c|}
\hline \multirow[b]{2}{*}{$\begin{array}{c}\text { Nutritional } \\
\text { composition } \\
\text { (g/100g DM) }\end{array}$} & \multicolumn{7}{|c|}{ Forage species } \\
\hline & $\begin{array}{l}\text { Sambucus } \\
\text { peruviana }\end{array}$ & $\begin{array}{c}\text { Otholobium } \\
\text { munyense }\end{array}$ & \multicolumn{2}{|c|}{$\begin{array}{c}\text { Salix } \\
\text { humboldtiana }\end{array}$} & $\begin{array}{l}\text { Sambucus } \\
\text { nigra }\end{array}$ & $\begin{array}{c}\text { Genitsa } \\
\text { monspessulana }\end{array}$ & $\begin{array}{c}\text { Hibiscus } \\
\text { rosa } \\
\text { sinensis }\end{array}$ \\
\hline DM & 14.43 & 21.97 & \multicolumn{2}{|l|}{22.11} & 20.38 & 34.2 & 25.69 \\
\hline $\mathrm{CF}$ & 10.29 & 15.51 & \multicolumn{2}{|l|}{20.81} & 7.81 & 19.93 & 13.96 \\
\hline $\mathrm{CP}$ & 25.93 & 22.47 & \multicolumn{2}{|l|}{21.11} & 21.8 & 19.58 & 15.62 \\
\hline $\mathrm{EE}$ & 3.87 & 6.68 & \multicolumn{2}{|l|}{2.29} & 4.78 & 3.45 & 13.09 \\
\hline NFE & 48.85 & 45.59 & \multicolumn{2}{|l|}{48.26} & 57.16 & 52.61 & 49.43 \\
\hline $\mathrm{A}$ & 11.06 & 9.74 & \multicolumn{2}{|l|}{7.53} & 8.46 & 4.42 & 17.89 \\
\hline NDF & 31.21 & 37.34 & \multicolumn{2}{|l|}{47.18} & 23.66 & 47.15 & 48.5 \\
\hline $\mathrm{ADF}$ & 20.94 & 23.09 & \multicolumn{2}{|l|}{31.54} & 15.43 & 28.76 & 16.48 \\
\hline HEM & 10.27 & 14.25 & 15.64 & & 8.23 & 18.38 & 32.02 \\
\hline \multirow{2}{*}{$\begin{array}{c}\text { Nutritional } \\
\text { composition } \\
\text { (g/100g DM) }\end{array}$} & \multicolumn{7}{|c|}{ Forage species } \\
\hline & $\begin{array}{c}\text { Verbesina } \\
\text { arborea }\end{array}$ & $\begin{array}{c}\text { Baccharis } \\
\text { latifolia }\end{array}$ & $\begin{array}{l}\text { Cyclanthera } \\
\text { brachystachya }\end{array}$ & $\begin{array}{c}\text { Ambrosia } \\
\text { arborescens }\end{array}$ & $\begin{array}{c}\text { Abutilon } \\
\text { pictum }\end{array}$ & \multicolumn{2}{|c|}{$\begin{array}{c}\text { Tithonia } \\
\text { diversifolia }\end{array}$} \\
\hline DM & 18.34 & 26.1 & 8.79 & 25.12 & 28.66 & \multicolumn{2}{|c|}{17.03} \\
\hline $\mathrm{CF}$ & 10.54 & 13.32 & 21.59 & 11.36 & 10.66 & \multicolumn{2}{|l|}{7.35} \\
\hline $\mathrm{CP}$ & 18.42 & 18.58 & 21.35 & 21.71 & 23.42 & \multicolumn{2}{|l|}{21.44} \\
\hline $\mathrm{EE}$ & 5.53 & 6.71 & 4.13 & 5.01 & 3.01 & \multicolumn{2}{|l|}{2.91} \\
\hline NFE & 52.23 & 51.84 & 38.49 & 48.75 & 49.1 & \multicolumn{2}{|l|}{48.51} \\
\hline $\mathrm{A}$ & 13.28 & 9.55 & 14.45 & 13.17 & 13.81 & \multicolumn{2}{|l|}{19.78} \\
\hline NDF & 41.96 & 47.79 & 38.06 & 33.25 & 48.15 & \multicolumn{2}{|l|}{32.69} \\
\hline $\mathrm{ADF}$ & 28.6 & 32.13 & 27.23 & 23.31 & 17.02 & \multicolumn{2}{|l|}{21.50} \\
\hline HEM & 13.37 & 15.66 & 10.83 & 9.95 & 31.13 & 11.19 & \\
\hline
\end{tabular}

DM: Dry matter; CF: Crude fiber; CP: Crude protein; EE: Ether extract; NFE: Nitrogen - free extract: A: Ash; NDF: Neutral detergent fiber; ADF: Acid detergent fiber; Hem: Hemicellulose.

The highest percentage of $\mathrm{CF}$ was present in C. brachystachya, with $21.6 \%$, compared to $T$. diversifolia, with 7.4\%. Fiber in the herbivore diet is defined as "the portion of indigestible or slowly digestible foods that take up space in the gastrointestinal tract." This definition excludes plant cell wall polysaccharides that are rapidly fermented and soluble polysaccharides that do not take up space in a liquid environment. However, it includes slowly fermentable polysaccharide complexes in the digestive tract of herbivores such as cellulose and hemicellulose (Mertens, 2002).
In the same way, excess fiber reduces the capacity for food ingestion, the digestibility of the ration, the synthesis of ruminal microbial protein and the energy supply. On the contrary, in high-production animals, in which the ration must have a high energy density, the recommendations are concerned with establishing minimums. The lack of fiber results in a decrease of the fat in milk, acidosis, laminitis, and displacement of the abomasum due to physical or fermentative imbalances (Hernández, 2010). 
In the same way, given the characteristics of tropical grasses with digestible protein and high fiber, the foliage of arboreal and shrub species can, in many cases, constitute a nutritional strategy in animal feeding, mainly during periods of forage scarcity. The reason is the fact that many of these species have higher feeding values than those of grasses and can produce high amounts of edible biomass that are more sustained over time under conditions of zero fertilization.

Regarding the fiber fractions, it was found that the NDF of $H$. rosa sinensis presented the highest value with $48.5 \%$, and S. nigra presented $23.7 \%$. Regarding ADF, a higher concentration was obtained in B. latifolia and a lower percentage in S. nigra with $32.1 \%$ and $15.4 \%$ respectively. Di-Marco (2011) states that a forage is of high quality when it has less than $50 \%$ of neutral detergent fiber (NDF) and more than $15 \%$ of crude protein; on the contrary, when a forage has an NDF above $65 \%$, it is considered of low quality. These indicators suggest that there are adequate levels of this component in the evaluated forages, which implies high quality.

The concentration of NDF in food is inversely correlated with the concentration of energy and its chemical composition. However, when they have similar concentrations of NDF, they will not necessarily have similar concentrations of energy. Thus, certain foods with high levels of NDF may have more energy available than others with a lower concentration of NDF. This is due to the composition of this fibrous fraction (NRC, 2001).

The analysis showed that $S$. peruviana had a greater amount of protein, $25.9 \%$, a value that exceeds that reported by Carvajal et al. (2012) $19.4 \pm 0.27$. S. peruviana is followed by A. pictum with $23.4 \%$ and $O$. munyense with 22.5\%. The lowest value was obtained by $H$. rosa sinensis with $15.6 \%$, appreciable levels for use in the diets of herbivorous animals, due to their low protein content, it results in a decrease in forage consumption, due to the low protein content in tropical forages Hence, the quantitative assessment of the protein content of the forage is the basis to know if it meets the requirements of the animal (Jiménez, 2007).

For the fraction corresponding to EE, H. rosa sinensis showed the highest content with $13.1 \%$. In this regard, Rivero (2016) states that most of the lipids in forages present low concentrations, and their proportion decreases as the plant matures. The contribution of EE from green pastures is between 2.5 and 3\% in dry matter. These include ryegrass, oats, alfalfa, grass, and legume meadows. Hay materials contain an average of $1.5 \% \mathrm{EE}$. The lowest value for this nutrient was seen in S. humboldtiana with $2.3 \%$. It is considered that the excess of EE in the ruminant's diet, especially if it is unsaturated fatty acids, can affect the ruminal flora. However, it is well established that a diet containing up to $5-6 \%$ EE in total dry matter does not alter ruminal function.

Forage potential is a concept that goes beyond nutritional value and includes at least two additional characteristics: voluntary consumption, as an initial indicator of animal response and the availability of the material in a sufficient and permanent fashion (Polanía and Rendón, 2009).

Anti-nutritional composition. Table 4 shows the results of the secondary metabolites, where the evaluated species present low tannins and sterols, except for $O$. munyense and $C$. brachystachya with moderate values. For saponins and alkaloids, most forages presented negative results, except for $S$. nigra at a low level. 


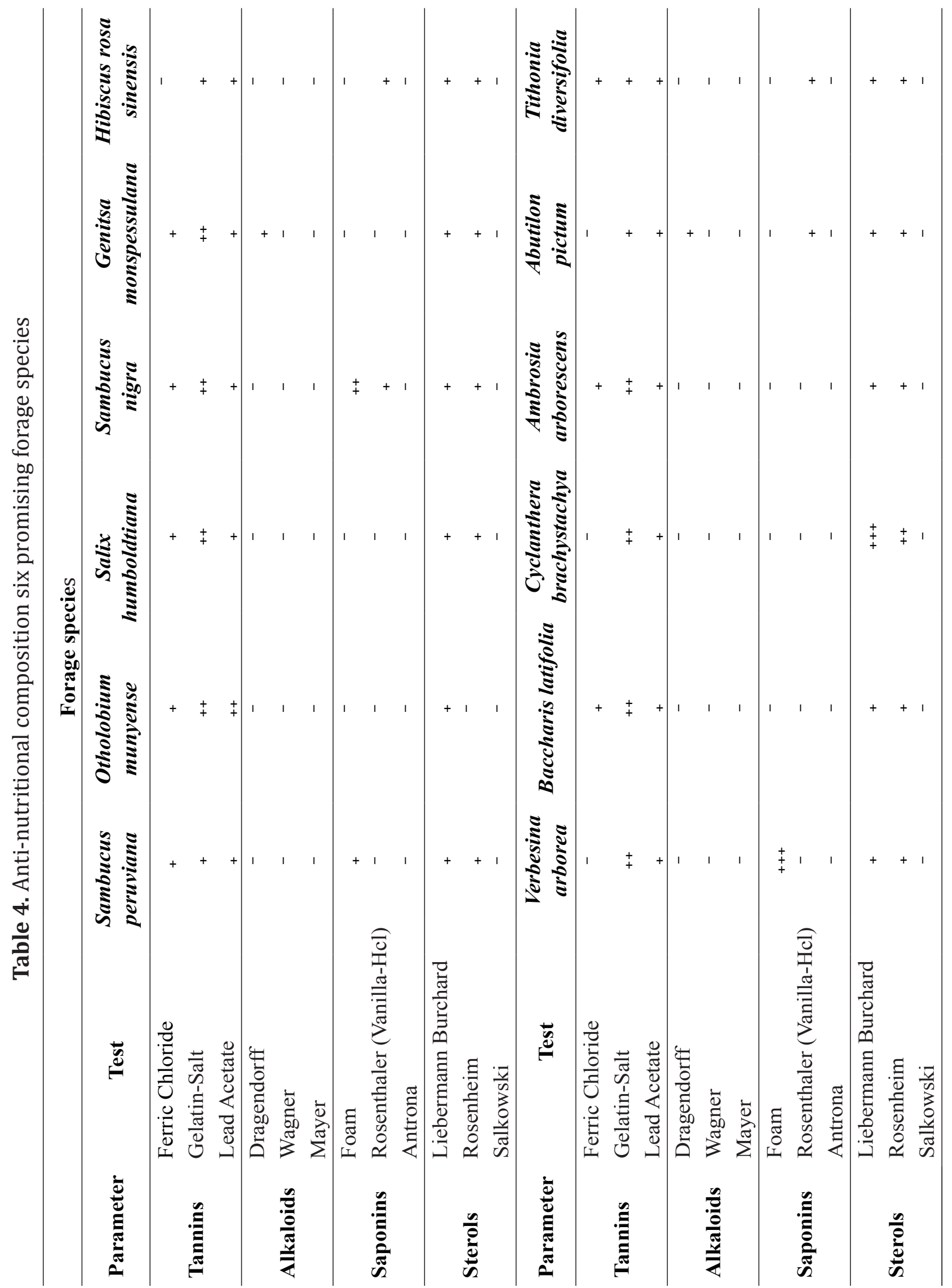


Due to the genetic and morphological diversity of the $B$. latifolia species, it is reasonable that its species develop an equally diverse secondary metabolism (dos Santos et al., 2016). At the phytochemical level, this plants are characterized by the presence in stems, roots, leaves and flowers of flavonoids, phenolic acids, coumarins, diterpenes, triterpenes, trichothecenes, polyacetylene and essential oils; the number of isolated and identified compounds was greater than 500 (Verdi et al., 2005).

The evaluated species presented a negative result for alkaloids, a factor that is related to the low digestibility of the feed. The negative value found makes these plant species suitable to be used in animal feed, since eventually they will there are no adverse physiological effects in animals.

Saponins can generate positive effects on the ruminal flora, reducing the concentration of ammonia and the emission of methane in the rumen (Patra and Yu, 2014; Inamdar et al. 2015), which allows a greater degradation of the particles and also a better use of the food.

The presence of phenols at low or moderate levels, from the nutritional point of view, is favorable. The reason is that in the diet of ruminants, the presence of phenols increases the possibility of formation of the bypass protein that is not degraded in the rumen. This facilitates postruminal digestibility and contributes to an adequate digestive function and a greater animal response (García and Medina, 2006). García and Medina (2006) mentions that the mechanism can be explained by the ability of phenolic compounds to form complexes with food or endogenous proteins through multiple bonds, creating a complex three-dimensional structure with low digestibility at the ruminal level.
For a shrub or tree to be considered as forage, it is important to take into account that the nutritional content is adequate, that its consumption promotes positive changes in the productive parameters, that the secondary metabolites do not affect its consumption or the normal physiological activities of the animal, that it is tolerant to management practices such as pruning and maintaining adequate biomass production (Sosa et al., 2004).

\section{CONCLUSIONS}

The agricultural sector is largely affected by the presence of intense rain and drought phenomena. In this sense, the evaluated species demonstrate their adaptation to the study area, which enhances their use in feeding herbivorous animals, such as co supplement the forage base in extreme environmental times, in which the grass is of low nutritional value complement the forage base in extreme environmental times, with disposition of biomass without competition with other agricultural activities.

This research allowed the identification of twelve species with forage potential. They are characterized by their high protein content, which can be considered for the incorporation of animal diets. The percentages of $\mathrm{CF}$, as well as their fractions, are variable; therefore, the type of animal species they are to be used in must be considered.

The anti-nutritional factors analyzed show an adequate content of tannins and negative values of saponins and alkaloids, which enhances their use and makes them an excellent supplementary alternative for feeding, mainly of ruminants and monogastrics herbivorous. 
The nutritional and antinutritional composition is just one of the elements that must be taken into account when evaluating a forage. It is recommended that further evaluations be made in order to determine agronomic behavior, palatability, productive yields, among others.

\section{ACKNOWLEDGMENTS}

The authors thank the University of Nariño for funding and granting us the access to the study area, laboratories, and herbarium.

Conflict of interest: The authors declare that there is no conflict of interest.

\section{BIBLIOGRAPHIC REFERENCES}

AOAC- Association of Analytical Communities. (2016). Official methods of analysis of AOAC international. $20^{\text {th }}$ Ed. Washington, D.C: Agricultural chemist.

Carvajal, T.; Lamela, L.; Cuesta, A. (2012). Evaluation of the arboreal Sambucus nigra and Acacia decurrens as a supplement for dairy cows in the Sabana de Bogotá, Colombia. Pastures and Forages. 35 (4). Retrieved from http://scielo.sld.cu/scielo.php?script=sci_artte xt\&pid=S0864-03942012000400007

Di-marco, 0. (2011). Forage quality estimation. Retrieved from http://www.produccion-animal. com.ar/tablas_composicion_alimentos/45calidad.pdf

dos Santos Gomes, J.; Félix-Silva, J.; Fernandes, J.; Amaral, N.; Lopes, E.; Tabosa do Egito, A.; da Silva-Júnior, S.; Zucolotto, M.; FernandesPedrosa, M. de F. (2016). Aqueous leaf extract of Jatropha mollisima (Pohl) bail decreases local effects induced by Bothropic venom. BioMed Res. Int. Article ID 6101742. doi: https://doi. org/10.1155/2016/6101742
García, D.; Medina, M. (2006). Chemical composition, secondary metabolites, nutritional value, and relative acceptability of ten forage trees. Tropical Zootechnics. 24 (3): 233. Recovered from http://www.scielo.org.ve/scielo.php?script=sci_ arttext\&pid=S0798-72692006000300004

Gómez, M.; Rodríguez, L.; Murgueitio, E.; Ríos, C.; Rosales, M.; Molina, C., Molina, E.; Molina, J. (2002). Forage trees and shrubs used in animal feed as a protein source: Marathon (Gliricidia sepium), Nacedero (Trichantera gigantea), Pizamo (Erythrina fusca) and Buttercup (Tithonia diversifolia). CIPAV, 129. Recovered from http://bibliotecadigital.agronet.gov.co/ itstream/11348/4048/1/20061024152517. Arboles $\% 20$ y $\% 20$ arbust os $\% 20 \% 20$ forrajeros\%20alimentacion\%20animal.pdf

Hernández, S. (2010). Importance of fiber in the feeding of bovines. Retrieved from http://mateandoconlaciencia.zonalibre.org/ AFIBRAENLAALIMENTACIONDELOSBOVINOS. pdf

Inamdar, A. I.; Chaudhary, L. C.; Agarwal, N.; Kamra, D. (2015). Effect of Madhuca longifolia and Terminalia chebula on methane production and nutrient utilization in buffaloes. Animal Feed Science and Technology. 201: 38-45. doi: 10.1016 / j.anifeedsci.2014.12.016

IDEAM - Instituto de Hidrología, Meteorología y Estudios Ambientales. (2018). Recovered from: http://www.bart.ideam.gov.co/wep/htm

Jiménez, P. (2007). Identification of cassava (Manihot esculenta Crantz) flours with high protein content by near infrared spectroscopy (NIRS). Recovered from https://cgspace.cgiar. org/handle $/ 10568 / 66188$ ?show=full

Mertens, D. (2002). Journal of AOAC International. Recovered from https://www.sciencedirect. com/science/article/pii/S0022030212001622

NRC - National Research Council. (2001). Nutrient Requirements of Dairy Cattle: Seventh Revised Edition, 2001. Washington, DC: The National Academies Press. doi: https://doi. org/10.17226/9825 
Ojeda, A.; Obispo, N.; Canelones, C.; Muñoz, D. (2012). Selection of woody species by cattle in silvo-grazing of a semi-deciduous forest in Venezuela. Archivos de Zootecnia. 61: 355 - 365. doi: https://doi.org/10.21071/ az.v61i235.2704

Patra, A.; Yu, Z. (2014). Combinations of nitrate, saponin, and sulfate additively reduce methane production by rumen cultures in vitro while not adversely affecting feed digestion, fermentation or microbial communities. Bioresource Technology. 155: 129-135. doi: https://doi. org/10.1016/j.biortech.2013.12.099

Pérez, A.; Montejo, I.; Iglesias, J.; López, O.; Martín, G.; García, D.; Hernández, A., (2009). Tithonia diversifolia (Hemsl.) A. Gray. Pastures and Forages. 32(1): 1-15.

Polanía, L.; Rendón, E., (2009). Baseline of arboreal and shrub species with forage aptitude in livestock production systems, in the Popayán peniplano. Retrieved from http://repositorio.unicauca.edu.co:8080/ bitstream/handle/123456789/724/ L \% c $3 \% 8$ d N E A \% 20 B A S E \% 20 D E \% 20 ESPECIES\%20ARB\%c3\%93REAS\%20Y\%20 ARBUSTIVAS\%20CON\%20APTITUD \% 20FORRAJERA $\% \quad$ 20EN\% 20SISTEMAS $\%$ 20DE\% 20PRODUCCI\% c3\% 93N\% 20GANA. pdf? Sequence $=1 \&$ isAllowed $=\mathrm{y}$

Rivero, F. (2016). Importance in ruminants of the nutritional contribution of the oil (ethereal extract) in the extruded soybean expeller. Retrieved from http://www.todoelcampo. com.uy/importancia-en-rumiantes-delaporte-nutricional-del-aceite-extracto-eteacute-reo-en-el-expeller-extrusado-de-soja15 ?nid $=23052$

Silva, A.; Garay, S.; Gómez, A. (2018). Impact of Alnus acuminata kunth on N2O fluxes and quality of Pennisetum clandestinum Hochst grass. Ex Chio. Colombia Forestal. 21(1): 47-57. doi: https://doi.org/10.14483/2256201X.11629

Sosa, E.; Pérez, D.; Ortega, L.; Zapata, G. (2004). Evaluation of the forage potential of tropical trees and shrubs for feeding sheep. Retrieved from http://www.redalyc.org/service/redalyc/ downloadPdf/613/61342201/1

Taiz, L.; Zeiger, E. (2010). Plant physiology. Retrieved from https://www.ncbi.nlm.nih.gov/ pmc/articles/PMC4242361/

Verdi, L.; Brighente, I.; Pizzolatti, M. (2005). Genus Baccharis: chemical, economic and biological aspects. Retrieved from https://www.scielo. br/scielo.php?script=sci_abstract\&pid=S010040422005000100017\&lng=pt\&nrm=iso 